\title{
THE LEFT HEGEMONY: THE ANDHRA EXPERIENCE FROM 1934 To 1956
}

\section{KANDUKURI RAMESH}

\author{
Deputy Director, Indira Gandhi National Open University, New Delhi, India
}

The Left Parties were united in exposing the 'Naked plunder' and ill effects of Colonial rule of the people of India. But they were fragmented on the methods, strategies and tactics in the fight against the Colonial power. The Congress Socialist Party (CSP) thrived for the establishment of Democratic Socialism and, the Congress aspired for complete independence, whereas, Communists strove for the establishment of a "Socialistic state." To achieve their respective goals, the two Left Parties chose different programs. While participating in anti-colonial movements with other Democratic Parties, Communists attempted to build a peoples' movement for a classless society. The CSP chose the parliamentary and other legal and open form of methods. Overall, the Left (parties) failed to understand the semi hegemonic, semi-suppressive character of the colonial state. Similarly, the Left could not assess the nature of the primary contradictions between British imperialism and the Indian people. On the whole, their hegemonic struggle was waged on a wrong terrain. "The Left believed that the National Movement should have a permanent mass and extra legal confrontation and conflict with imperialism, till it was overthrown."' The Communist Party of India's (CPI) application of Marxism in Toto was marred by ideological and tactical confusions. The policies, programs and political line of the Andhra unit of the CPI were adopted from the "Communist International (Comintern)" and the CPI. Further, Andhra Provincial Communist Committee's understanding of Colonialism, attitude towards National Movement, Gandhi and other Left Parties almost 'resembles' the official line of the CPI. An attempt has been made in this paper to study the theoretical and practical aspects of their ideology, and its implications with regard to their rise and fall in Andhra region i.e. residue Andhra Pradesh state.

KEYWORDS: Naked Plunder, Colonial Power, Socialistic State \& Imperialism
\end{abstract}

Received: Apr 10, 2017; Accepted: May 06, 2017; Published: May 17, 2017; Paper Id.: IJHRJUN20171

\section{INTRODUCTION}

\section{Isolation of the National Movement, 1934-35}

With the coordinated efforts of P. Sundaraiah, Andhra Branch of the CPI was formed in September 1934. Guided by the resolution of the Sixth Congress of the Comintern, the CPI broke its connection with the Indian National Congress and declared INC as a Class Party of the bourgeoisie. Similarly, Andhra Communists developed a hostile attitude towards the Congress Party to organize independent fronts by forming "labor protection leagues" in 1934. While drafting the constitution and programs, they made it a point to exclude the Congress members in giving the membership of the leagues. For example, Nellore Labour Protection League was formed on the 1st July, 1935 by P. Sundaraiah and other Communists. About the membership, its constitution stated, "One who is not a member of the Indian National Congress, or Communal organizations, or members of any other association, which are against the interests of the workers and who is above 15 years of age, and accepts the objects and the program are eligible for membership on paying one annual per year."2 P.V. Silvia in an article (October, 1934) entitled “Congress - Socialism” remarked, “.... It is not known why Congress men, who pay only temporary allegiance to 
nonviolent methods, should be afraid of Socialists. After all, serious clashes are inevitable at every step and at every moment between the Socialists, who are working for the real well-being of the laboring classes, and those Congressmen who profess to be striving for the same end." ${ }^{3}$ Communists continued to criticize the Congress Party on public platforms. A fortnightly report stated, "the youth and labor protection league continued to criticise the attitude of Congress to independent bodies of workers and peasants, and at a meeting of students in Masulipatnam (Krishna district), the Congress was accused of having changed into a liberal organization and of retarding the attainment of independence by protecting capitalists and vested interests." "However, very soon Communists realized that they were isolated from the mainstream of the National Movement due to their sectarian understanding of the Gandhi led freedom movement. The first sign of their rethinking was expressed in their draft political theses, it stated, "The CPI had committed serious mistakes with regard to participation in the anti-imperialist struggle, by limiting itself simply to general appeals to fight for an imperialist and antifeudal revolution without going into midst of the struggling masses." 5

As per the Comintern directives, the CPI formed the "United National Front" with the Congress Party. Similarly, its unit in Andhra was convinced with the new line of the party. Till their entry, the Communists criticized the CSP as reactionary and an appendage of the bourgeoisie, but with the United Front strategy,' the CSP was received as a 'sister Marxist Party'. Andhra unit of the CPI in its provincial conference at Kakinada (East Godavary district) in 1936 worked out a program of building independent mass organizations like Kisan Sabha, Trade union, Agricultural labor, women, student and youth organizations.

\section{Unity and Struggle in Action}

While implementing the united front strategy, Andhra Communists faced many problems with its allies; APCSP and Andhra Provincial Congress Committee (APCC). The Communists magnified the primary contradiction within the society and engineered the class struggles. P. Sundaraiah, while addressing the third APCSP conference at Rajahmundry stated, "There was a better chance Of establishing worker's and peasants' Government in the country, on the basis of Communism than on the basis of socialism and that, there was only one way of establishing it, and it was by a violent revolution." $\mathrm{He}$ further stated, "We will not have salvation unless the zamindars and capitalists and this bourgeoisie Government go."7 It had become a bone of contention between the Right and the Left wing of the APCC, whether the Congress Committees at district and taluk levels could initiate and conduct peasant struggles and Satyagrahas or not. The APCC took the hostile stand against the Left led struggles. Pattabhi Seetha Ramaiah directed the Congress Committees not to involve in peasant and workers' struggles, led by the Left. The Right wing of APCC followed the policy of "Class adjustment" and "Class collaboration". The APCC, which was under the firm influence of Right wing leaders took all counter measures to neutralize the movements, which are aimed to bring class conflicts that are led by the Communists. Communists were charged by them on flimsy grounds, and the result was their expulsion from the Congress Party. During the United Front period, the Communist Party broadened its social base in Andhra. Andhra PC organized many movements independently for the protection of the rights of aggrieved classes. Especially, it penetrated to downtrodden and exploited sections of the society. Its achievements are many fold; on the Kisan front, it organized Kalipatnam and Munagala peasant Satyagrahas; for workers, it organized ILTDC and Chittivalasa Jute mill strikes, successfully conducted the summer school of politics and economics in preparing Frontline leadership and committed cadre, religiously worked for the victory of Congress candidates in the 1937 elections, ${ }^{8}$ gained complete control over the APCSP. 


\section{IMPERIALIST-WAR, 1939-41}

The Congress Party was reluctant to start Satyagraha immediately after the outbreak of the World War II in 1939. In October 1940, it adopted an individual Satyagraha campaign under the leadership of Gandhi. The Communist Party differed with the program of the INC and stated that, the imperialist war should be transformed into a war of National Liberation, and appealed Congress leadership to adopt immediate measures to launch a mass struggle. The Communists were of the opinion that the Congress Satyagraha campaign would serve no useful purpose. They were of the view that the participation of the workers and peasants in the struggle for independence with their own weapons, their own forms of struggle would be more meaningful than the Congress Party's 'individual Satyagraha'. The Communists intensified their anti-war agitation. ${ }^{9}$ They opposed the move of the Congress Party's program of celebrating Independence Day, and as a counter move, it gave a radical plan of action. They instructed that, "Workers and students should strike work that day. All shop keepers should observe hartal, ryots, workers, and students, shop keepers, why for the matter of that, every person desiring independence should participate in the programme which the local Congress committees will carry out and make a grand demonstration against imperialistic rule and the war and for independence." 10 A confidential report reads, The Communist Party appealed the people to refrain from the reformist programmes of the Congress Party, their circular reads: "We, the Communists once again warn the Congress and the people that this world war is most convenient now for getting independence. There is no use of looking forward at those, who are in the attempts at compromise." 11 However, the Communist's war slogans and appeals go unheeded by the masses. A new 'turn' in the Second World War came with Hitler Germany's attack on the Soviet Union in June 1941. The Communist International gave the slogan of "People's War" and appealed all Communist parties around the world to support the war efforts of England and USSR i.e. Triple Entente. The "People's War policy" of the CPI reached its provincial units only in the middle of 1942. Andhra provincial committee of the CPI accepted the People's War line without any reservations. Even a single one of the 1000 PMs (Party Members) did not oppose the People's War policy. ${ }^{12}$ It adopted anti-struggle, anti-strike line. A line of avoiding mass struggles was worked out on the plea that they would damage the war efforts or help pro-fascist elements to sabotage. To help the British war efforts, it gave the programme "grow more food". ${ }^{33}$ The new programme of the party failed to convince the workers, as a result, it started losing its control over the workers' unions. The Andhra PC got demoralized with the severe exposition of the Central Committee (CC). The Andhra PC now decided to implement the CC line. It applied the slogan of 'more production' and anti-strike policy to all industries and chalked out a programme for all the trade unions, though unwillingly and as a matter of discipline. However, in some occasions the PC escaped the implementation of this slogan, by arguing in the following way, "the Party policy is against conducting strikes, so, we do not encourage the workers to strike. But, we have to support the workers if they spontaneously come out on a strike."14

The CPI directed the provincial committees to work with zamindars, land lords and upper class for more production to meet the food crisis that erupted due to the war. As a result, Andhra unit of the party kept on hold, the peasant struggles. This can be seen from one of its reports, "We sent Kisan Sabha leaders to even Challapalli and Munagala zamindars to seek their co-operation for our 'grow more food' campaign, which we had been fighting tooth and nail till then." ${ }^{\prime 5}$ Despite some reformist understandings, the Party fought against black marketers ${ }^{16}$ and led Jathas' to the collect orate offices on behalf of riots. ${ }^{17}$ The Andhra Communists branded the activities of APCSP, Forward Block and Ranga group as 'fifth columnists'. Many of these leaders were criticized in the party paper Prajashakti for opposing the British government in the Second World War. The 'so-called' fifth columnists started calling the Communists as adopted sons of Moscow. ${ }^{18}$ This widened the gulf between the Communists and the Left youth. ${ }^{19}$ The main achievements of the 
Party during the People's War period (1942-45) were that, it successfully organized an AIKS conference in Vijayawada and brought out "Prajashakti" weekly as then daily. ${ }^{20}$ But, they were isolated and marginalized in the National Freedom Struggle. $^{21}$

\section{POST - WAR AND INDEPENDENCE: 1945-47}

Due to People' War policy of the Andhra Provincial Communists, a state of 'civil war' existed between the APCC and Communists. Further, Communists were excluded from the Congress bodies. Andhra PC was divided on the issue of contesting in the 1946 elections. For the first time, the Party contested for 30 seats independently in the Provincial Assembly Elections. The Communist Party polled $22 \%$ of the total votes polled in the province as a whole. The Communist Party followed 'Confrontationist Policy' with the Congress Ministry. This policy of the Communist Party led to indulgence of large scale intimidation on the Communists by the Congress Ministry. M. Chandra Shekar Rao, in an article in "Prajashakti" criticised the Congress Ministry for following the footsteps of British imperialism to safe-guard the exploiting classes. ${ }^{22}$ Substantial mobilization was done against the zamindari estates like: Challapalli, Munagala, Meergapuram and Vuyyur of Krishna district. ${ }^{23}$ A Confidential Report remarked, "Since about the middle of 1946, Communist activity on the Kisan and labor fronts increased by tremendous strides, mainly through the means of the Party organisations and also by means of leaflets, booklets, public speeches and personal contacts."24

The Andhra PC fell in 'division' on the issue of celebrating the Independence Day. Minority comrades opined that, only Congress flag should be printed on the first page of the special Independence number Prajashakti (1947 August number), and only Congress flag should be hoisted on the office on the above occasion. Whereas, the majority comrades argued that both Congress and Red Flag should be printed and hoisted. Thus, a small tussle arose between the majority and minority trends on the issue of celebration of the first Independence Day. The majority comrades agreed at last to the printing and hoisting of only the Congress Flag, having both the flags would go against Party policy. They also agreed to celebrate the 'Independence Day', jointly with the Congressmen, and to celebrate it independently only in case Congressmen did not agree to join celebrations. ${ }^{25}$ Similarly, Communists also joined birthday celebrations of Nehru. ${ }^{26}$

\section{ADVENTURIST PHASE: 1948-50}

1948-1950 are the most turbulent years in the history of the Andhra Communist Party. During this period, Andhra PC proposed new political line and programmes to the CPI. Having broken completely with the reformist policy which had been following since 1942, the CPI passed a new political resolution in December 1947. The earlier policy of supporting the Nehru Government was abandoned. The provincial conference of the Andhra PC was held at Budhavaram in January 1948. The conference passed three amendments to the December Resolution of the CC of the CPI. P. Sundaraiah could not agree completely with the first amendment and kept neutral in the voting on the first amendment. ${ }^{27} \mathrm{P}$. Sundaraiah expressed that the political attitude he had been taking in the case of $\mathrm{CC}$ and Andhra PC was completely wrong and felt, continuation of his leadership of the provincial committee would not be correct. Accordingly, C. Rajeshwar Rao was elected as the Secretary of Andhra PC in Budhavaram (January 1948, Krishna district) Conference and Sundaraiah was given the responsibility of the Telangana front, where the class struggle was being conducted intensely. ${ }^{28}$ The Second Congress of the CPI was held in Calcutta from28th February to 6th March 1948. A 'New Line' was adopted in this conference. 


\section{Telangana Way: Andhra Thesis}

The Calcutta Conference extolled the Telangana struggle and raised the slogan "Telangana way is our way." It had declared all out support to the armed struggle of Telangana people. In the conference, the comrades from other parts of India promised that, they would start similar revolts in their states to strengthen the Telangana struggle, which would ultimately lead to country wide insurrection. ${ }^{29}$ They argued that the Bolshevik Revolution could not be the model for India because, "Our revolution in many respects differs from the classical Russian Revolution, and is to a great extent similar to that of the Chinese Revolution. The perspective is not that of general strikes and general uprisings leading to the liberation of the rural side, but the dogged resistance and prolonged civil war in the form of an agrarian revolution culminating in the capture of political power by the democratic front.” The CPI General Secretary B.T. Ranadive, who proposed the Russian path, rejected the Andhra thesis as "anti-Party and anti Leninist and attacked the Andhra Communists for advocating the Maoist strategy for India." ${ }^{30}$ As the Russian path failed, B.T. Ranadive was removed and Chandra Rajeshwar Rao, the main architect of Andhra thesis was elected as the new General Secretary of the CPI. As an extension of Telengana Armed Struggle, Andhra PC also launched their unit in guerrilla struggles.

Many agrarian struggles were fought. The occupation of zamindari estate lands in challapalli, the reoccupation of illegally seized lands in Munagala, the struggle in Krishna Lanka, Kanur, Pendyala Lanka struggle etc., province wide agitation on the demands of tenants and a few rent reduction struggles were conducted. However, extension of guerrilla struggle in Andhra was opposed by the Guntur district unit member Vemulapalli Sri Krishna, who was expelled from the Party in 1949 for opposing the extension of Telangana movement in Andhra Region. He told the Party that they are following wrong tactics. Undeterred with the opposition and criticizing them as reformist, opportunists, the Party continued to organize the liberation struggle. They have taken a programme 'purge'. According to this, it decided to remove or expel the cadre of the Party, who were opposing the struggle. Within one year, out of 21,000 memberships 14000 members were removed from the Party membership. To contain the Communists armed struggle, the government of India took several stringent measures. ${ }^{31}$ Similarly, Madras government held provincial conferences to check the Communist movement. On 26th September 1949, the Madras government declared all the associations named on Communist Party as unlawful. ${ }^{32}$ A charge sheet against the communists was prepared, and Malabar special police was deployed in the region. ${ }^{33}$ The Congress Party also formed 'sevadals' to counter the Communist menance. ${ }^{34}$ The victory of the Maoist line of peasant partisan warfare as the valid strategy of Indian revolution, for which, the Andhra Communists had so ardently fought was to be rather ephemeral. The base areas of the peasant guerrilla warfare in and around Telangana were virulently liquidated. Thus, 'Agrarian Revolution' proved no more successful than 'urban insurrection. ${ }^{35}$ The dwindling position of the Guerrilla struggle in Andhra can be ascertained from several fortnightly reports. The 'Chinese path' of Andhra PC further depleted the Communist movement in Andhra.

With the series of ideological fallouts, the CPI and the CC members fell in introspection. It appointed a three men committee to review the party line. The CC members, S.A. Dange, Ghate and Ajoy Gosh submitted a document on $30^{\text {th }}$ September 1950. It finally suggested the CC for fraternal assistance for authoritative interpretations of the party line. A top level CPI delegation consisting of S.A. Dange, A.K. Ghosh, M. Basava Punnaiah and C. Rajeshwar Rao, paid a clandestine visit to Moscow. The CPSU appointed a four member committee headed by Stalin, the other members were, Maltov, Malenkov and Suslov. The CPI delegation came back to India with two documents; "New draft programme" and the "Tactical line", both drawn in consultation with the Soviet leaders. In May 1951, the CPI abandoned the Chinese form of 
guerrilla warfare, Rajeshwar Rao, who had succeeded Ranadive in June 1950 as a General Secretary of the Party resigned. A Centrist, Ajoy Ghosh was elected as the General Secretary of the CPI.

The government of India declared the First General Elections in 1952. Top leaders of the Andhra, who were spearheading the armed struggle in Telengana were in underground. A.K. Gosh, the CPI General Secretary, without consulting the underground Andhra leadership constituted an "Election Committee". From the elections, the Communist party emerged as a major political force in Andhra next to Congress party, by bagging 41 seats. But, in midterm elections 1955, it distanced the same forces where it aspired totally in 1952 elections. The Communist bloc, which claimed to form the government, underwent humiliating defeat. It had drawn blank in Rayalaseema districts. It is the result of the wrong tactics of PC, which failed to form an electoral alliance with the other Left parties and the Democratic Forces, and chose to fight alone.

\section{ORGANIZATIONAL AND IDEOLOGICAL DIFFERENCE}

By the time of withdrawal of the Telengana armed struggle in 1951, severe differences existed between the legal cadre and underground cadre on the one hand, and Telangana leadership and Andhra leadership on the other hand. P. Sundaraiah wrote a letter entitled "on our differences", “...The most important difference is on the question of how to fight back the efforts of the Congress Government and the landlords to evict the peasants from the lands they are cultivating. It is on this issue, that the sharpest differences have arisen in all places, and they became a daily feature, between Ravi Narayana Reddy group and the legal cadre on the one side and the underground cadre on the other." ${ }^{\text {, }}$ The organizational differences went to the extent of functioning of Telangana and Andhra Committees, separately. About the differences in the Party, P. Sundaraiah stated, "already existing differences in the Party after 1955 elections in Andhra were further intensified. From 1953 onwards, on every occasion, quite divergent and opposite resolutions were introduced, somehow a compromise resolution would be passed, and every one used to twist it to their own language."37 Finally, in Palghat Conference in 1956, the CPI recognized India as an independent state and supported the democratic elements in the Congress Party. ${ }^{38}$ However, ideological differences continued in the Vishalandra unit. This division continued till the Party's vertical split in 1964.

It is a fact that the spread of Communist Party in Andhra was largely due to the efforts of the predominantly young leadership, hailing from three upper castes such as: Kamma, Reddy and Brahmin. Scholars led by Selig Harrison attributes the origin of Communist Party in Andhra due to the caste rivalries for political supremacy between the Reddy's and Kammas. ${ }^{39}$ G.S. Bhargava, who considerably contributed his study on Andhra Communists argues that, since the founding of the Andhra Communist Party in 1934, the Party leadership has been the property of a single sub caste, the

Kamma landlords. ${ }^{40}$ But, their articulation needs reinterpretation. In 1934, an organizing Committee was formed in Andhra with seven members. But, the caste position of these seven members did not support the arguments of G.S. Bhargava (see table): 
Table 1: The Organizing Committee Members of the Andhra Unit in 1934

\begin{tabular}{|c|l|l|l|l|}
\hline S. No. & \multicolumn{1}{|c|}{ Name } & \multicolumn{1}{c|}{ District } & \multicolumn{1}{c|}{ Cast } & \multicolumn{1}{c|}{ Class } \\
\hline 1 & P. Sundaraiah & Nellore & Reddy & Rich \\
\hline 2 & K. Seshaiah & Guntur & Brahmin & Poor \\
\hline 3 & A. Satyanarayana & West Godavari & Raju & Rich \\
\hline 4 & P. Narasimha Murthy & Guntur & Brahmin & Poor \\
\hline 5 & T. Venkata Chalapathi & West Godavari & Brahmin & Poor \\
\hline 6 & M. Chandra Shekhar Rao & Krishna & Kamma & Poor \\
\hline 7 & Ch. Vasudeva Rao & Krishna & Kamma & Rich \\
\hline
\end{tabular}

Similarly, Harrison's Thesis, Origin and spread of the Communist movement in Andhra was due to Kamma Reddy rivalry. This is also not borne out of the fact.

Table 2: Brahmin Leadership of the Andhra Communist Party

\begin{tabular}{|c|l|l|l|}
\hline S. No & \multicolumn{1}{|c|}{ Name } & \multicolumn{1}{c|}{ District } & \multicolumn{1}{c|}{ Cast } \\
\hline 1 & PV Seshaiah & Guntur & Brahmin \\
\hline 2 & N Prasada Rao & Guntur & Brahmin \\
\hline 3 & K Satyanarayana (Senior) & East-Godavari & Brahmin \\
\hline 4 & K Satyanarayana (Junior) & Guntur & Brahmin \\
\hline 5 & P Venkateshwerlu & Krishna & Brahmin \\
\hline 6 & V Gopala Krishanaiah & Guntur & Brahmin \\
\hline 7 & Y Balarama Murthy & Guntur & Brahmin \\
\hline 8 & P Rama Subhaiah & Guntur & Brahmin \\
\hline
\end{tabular}

Table 3: Kamma Leadership in the Communist Party

\begin{tabular}{|c|l|l|l|}
\hline S. No & \multicolumn{1}{|c|}{ Name } & \multicolumn{1}{|c|}{ District } & \multicolumn{1}{c|}{ Cast } \\
\hline 1 & Chandra Rajeshwar Rao & Krishna & Kamma \\
\hline 2 & Vemulapalli Sri Krishna & Guntur & Kamma \\
\hline 3 & Korapati Pattabhi Ramaiah & Guntur & Kamma \\
\hline 4 & Kadiyala Gopal Rao & Krishna & Kamma \\
\hline 5 & Maddukuri Chandra Shekhar Rao & Krishna & Kamma \\
\hline 6 & Y V Krishna Rao & Krishna & Kamma \\
\hline 7 & Katragadda Raj Gopala Rao & Krishna & Kamma \\
\hline 8 & M Basava Punnaiah & Guntur & Kamma \\
\hline 9 & M Hanumantha Rao & Guntur & Kamma \\
\hline 10 & Dr. Radha Krishna Murthy & Guntur & Kamma \\
\hline 11 & Kolla Venkaiah & Guntur & Kamma \\
\hline 12 & Moturi Udayam & Guntur & Kamma \\
\hline 13 & L Bala Gangadhar Rao & Guntur & Kamma \\
\hline 14 & Garapati Satyanarayana & West Godavari & Kamma \\
\hline
\end{tabular}

From the above tables, it is understood that the Communist Party in Andhra was represented by all upper castes, however, dominated by Kamma leadership. Three Kamma intellectuals, Chandrashekar Rao, C. Rajeshwar Rao, and Basava Punnaiah played a vital role in formulating the policies of the Party. Carolyn M. Elliot, who has made an in-depth study of the role of the 'Dominant Castes' 'Reddies and Kammas'- in Andhra politics does not accept Harrisons thesis completely. "The Communist movement, comments Elliot, did not represent a continuation of the sentiments, which firstly enlarged in the castle hosted movement and continued in the justice Party and self-respect movement." ${ }^{, 1}$ Polepeddi Narsimham, Kambhampati Satyanarayana (senior), Sundaraiah and Nanduri Prasad Rao were some of the provincial nonkarma leaders, who were associated with the Andhra Communist movement right from its genesis. Carolyn rightly stated, "the CPI leadership consisted many Brahmins and Reddys and horizontal solidarities can be explained more in terms of 
class than caste." ${ }^{42}$ Thus, it can be concluded that, the presence of Kamma leadership is more on historical accident than a deliberate factor. The socioeconomic background of the leadership of the Communist Party in Andhra represents rich peasant with middle class ideology. Although a large number of Kamma and other forward castes were active in the CPI, the Party did not project any pro-Kamma or pro-landlord policies. On the contrary, the Andhra Communists have been perhaps more revolutionary than their counterparts in any other state. ${ }^{43}$ It is a fact that, the entire leadership of the Andhra Communist Party was drawn from upper castes, but they are not feudal elements as stated by the C.V.K. Rao, who was expelled from the Party for anti Party activities. He coined a word "KulakPettamdar" to describe the domination of the particular caste in the Party. ${ }^{44}$ A resolution was passed under his leadership on June 20, 1954 at a meeting of Communist workers of East Godavari held in Kakinada. The resolution was printed in a pamphlet entitled, "the bluff of the Andhra Communists". The statement reads: 45 "The feudal landlord elements of Andhra have brought the Congress under its thumb and swallowed it. In the Communist Party also the same elements have captured the leadership and are following a dictatorial policy. There is no freedom of expression in the Party. The leadership has prevented the principle of criticism and self criticism, and is keeping the rank and file under its thumb with false propaganda, threats of stoppage of allowances and bits of power in the Party. If any member is bold enough to challenge them, he is marked down, painted as an enemy of the Party and ultimately driven out." Instances of this kind are available from every district. If the rank and file protests against, their attention is side tracked with connoted tales against the expelled members. The resolution questioned the recruitment and promotion of the kins of the leadership. "The provincial headquarters is packed with the sons of Kulaks, who have received the seal of approval of the leadership as officer cadre. They are then promoted as leaders, and sent out to the districts to spy on the Party workers. These 'born leaders' boss over the real cadre, whom have to obey them.

\section{CONCLUSIONS}

The Left Parties in general and the Communist Party in particular, failed to see the primary contradiction between the colonial people and imperial rule, and magnified the contradiction that existed within the colonial society. The strategy they followed was a continuous 'underground warfare' as against the Gandhi's war of position and war of movement, combined together depending upon the political participation of the masses. Andhra Communists followed the sectarian policy of the CPI in 1934. They did a tactical mistake by denying the membership to the Congress Party members in the labor protection leagues, and started criticizing the Congress as bourgeoisie organization. But, with the formation of the Broad United Front, Communists joined the APCSP and thereby made their entry in the Congress Party. In the guise of 'Broad United National Front', the Andhra Communists worked sincerely to broaden their mass base, by forming independent organizations. Again, their contradictory and antagonistic programs and mass struggles paved the way for their expulsion from the Congress Party. The reason for their expulsion was that, they intensified the class struggles and class hatred, instead of working for the National Freedom Movement. With the outbreak of the Second World War (1939), the Andhra PC appealed the people to transform the imperialist war into a war of National liberation and criticized Gandhi's 'individual satyagraha'. But, their appeal went unnoticed by the masses.

With the Hitler's attack on Russia, in mid 1942, the CPI gave the slogan 'People's War', and reversed its earlier policies and followed a fully fledged reformist line, like anti-strike and anti-struggle and grow more food by allying with zamindars and landlords. In fact, one section in the Andhra PC opposed the reformist line of the CPI, but the 'discipline rod' was used against them. The Party resorted to criticizing the Left Nationalists as fifth columnists, who were enjoying the great sympathy of the people for their 'patriotic' activities. Thus, a bad scene was created, where, the severe clashes 
erupted between the Communists and Left Nationalists. In the 1946 elections, the Party polled 22 percent of the total votes polled in the province. After the attainment of India's independence, the CPI left the reformist line and thus began the adventurist phase till 1950. At Budhavaram Party Conference (January 1948), the differences that existed in the Party went to the extent of relieving P. Sundaraiah from his duties in Andhra and was given the responsibility of the Telangana armed struggle. Most of the Andhra delegates in Calcutta conference supported the 'insurrection line' of B.T. Ranadive. After the conference, Andhra Comrades prepared a document called Andhra thesis, where they invoked 'China's line' as against the B.T.R.'s 'Russian Model', to seize the political power in India. BTR criticized Chinese line, but when Cominform journal supported Chinese line in January 1950, he accepted his mistake. To form the liberation basis, Andhra PC extended the guerilla warfare into Andhra region in support of Telangana struggle. Many district units rightly opposed the decision of Andhra PC. In the name of 'purge', all such members, who were opposing the Party line were expelled from the Party reducing its membership from 21,125 to 6,990 .

The government took several counter measures to check the Communist violent activities, and its measures proved to be successful. By extending the guerrilla struggle in Andhra region on the whole, Party achieved nothing except losing its valuable cadre in the police firing and encounters. This strategy of the Party proved to be a death blow to the movement. With the failure of 'Russian' and 'Chinese' models, the CPI looked towards Russia for guidance. Thus, came the Moscow documents, where the CPI evolved the 'Indian Path' in 1951. Due to the changed line of the party and disintegrating guerilla armed struggle, the Party had withdrawn the Telangana Armed Struggle when the movement was almost at the fading stage. The post-Armed struggle Phase (1951-56) in Andhra was the phase of severe internal differences in the Communist Party. Their differences came to climax after the midterm (1955) elections in Andhra. It was the end of its glory and beginning of its downfall. The divisions and desertions brought disaster to the Communist party and ultimately led to its split in 1964. The young Kamma intellectuals played a pivotal role in sowing the seeds of Socialism in Andhra region, and the non Kamma castes also equally contributed in the consolidation of the Communist Party in Andhra. The political consciousness of the Kamma leadership was much above than a leader, with caste aspirations. The whole Andhra PC Secretariat from its genesis in 1934 to 1956 was occupied by upper caste people. Provincial leadership hails from certain upper caste only, this may be attributed to its organizational weakness, and the Party could not develop and promote the cadre of down trodden classes to leadership level. The other Left Parties in Andhra such as APCSP and RDP failed to make inroads in Andhra region. Thus, the Left did not succeed in transforming the Congress into a revolutionary organization. Equally, it could not succeed in attempting people's democratic revolution and also registered mixed response in electoral participation.

\section{REFERENCES}

1. Bipan Chandra, "Struggle for the Ideological Transformation of the National Congress in the 1930s"Social Scientist, no. 159 160, August-September 1986, p. 26, and Sashi Joshi, "Nehru and emergence of the left Bloc" in Bipan Chandra (Ed) (1983). The Indian Left: CriticalAppraisal, New Delhi 45.

2. Venkata Rangaiah. M (ed) (1974). The Freedom Struggle in Andhra Pradesh (Andhra), vol. iv, Hyderabad, Document no.86, p. 647, Dhurba Krishnamurthy brought an amendment to enable to give membership to the Congress members the amendment reads: "The people believe that Congress Party is an anti-imperialist organization. it is the mass organization which led many movements for freedom". When put to vote. D. Krishna Murthy, (1985). Smrutulu (Remniscences in Telugu) Madras, 47-48.

3. Public (General) department, Dis. no. 285/34, dated 24October 1934. 
4. Fortnight Reports Second Half (FNR, SH) of December 1935.

5. Sobhanlal Gupta, Comintern India... opcit, p.214.

6. Home (Confidential) G.O. No. 2618-19, Dated 7/10/1936.

7. Ibid.

8. Third Andhra Communist conference (1948 July, 8-15), reports resolutions, Prajashakti, pub. No. 23, Vijayawada, 1943, p. 8.

9. In its appeal stated, "Be ready to fight, you must join as volunteers do not help the Britishers in any way. Do not send men to the army. Do not deposit money in the bank. Take away all deposited amounts from the bank." G.O.No.815, public (General), 1940, Department, dated 28-4-1940, G.O. No.505, public (General), 1941 department, dated 7-3-1941.

10. A secret circular issued by the CPI unit of East Godavary District G.O. No.857, public (General), 1940, dated 26-4-1940.

11. Swatantra Bharat Vol.2, Issue No.1, 3-9-1940, G.O. No.367 (General) 1941, Department, dated 21-2-1941.

12. Self Critical Report of Andhra Provincial committee Secretariat (1942-49) p.4.

13. Guidelines of the History of the CPI... opcit, p.65.

14. Ibid, p.12.

15. Ibid, p.14.

16. FNR, SH, June 1943, FNR, FH, July 1943.

17. FNR, FH, October, 1942

18. Self Critical Report.. opcit, p.8.

19. Ibid, p.9.

20. Andhra State Committee Plenum Meeting, 1944 July 11th-19th Prajashakti pub.No. 76, Vijayawada, 1944, pp.8-10.

21. For detail of their role in freedom movement, see ChapterIV of the book, The left legacy: The Andhra Experience 1934-56, Ruby press\&Co, New Delhi,2014

22. Self Critical Report... opcit, p.36.

23. G.O.No.2615, public (Confdl), dated 21-8-1947.

24. Home Political, 7-1-1945, NAI.

25. Ibid, p.55, and Report on the Admn of the Police of the Madras Province, 1947, p.40.

26. FNR, SH, November 1947.

27. Self Critical Report... opcit, p.59

28. Ibid, p. 61 .

29. Sundaraiah.P, (1972). Telangana People's Struggle and itsLessons, Calcutta 394.

30. Hemen Roy, Peking and the Indian Communists... opcit, p.12.

31. "Communist Subversive Propaganda and suggested Methods to Counter it ", Intelligence bureau, Ministry of Home Affairs, USSF, No.24/1949, Madra Archives.

32. Telegram No. 2818, dated 29th March 1948, No.S/1208/48. 
33. In a Press Communique issued by the Madras Government, dated 26-9-1949 stated, taking advantage of the disturbed conditions prevailing in the areas bordering Hyderabad, The Communists of the Circular districts in collaboration with state communists of Telangana are continuing a programme of murder and loot, USSF, No. 110/49, dated16-12-1949.

34. USSF, No.9/51, dated 2-2-1951.

35. Ashish Kumar Roy, Spring thunder... opcit, p.17.

36. Sundaraiah.P, Telangana People's... opcit, p.434.

37. Sundaraiah. P, (1988). Viplava Padamlo Na payanam (Autobiographyin Telugu) vol. ii Vijayawada, 117.

38. Javeed Alam, (1991). "State and the making of Communist politics in India, 1947-57" Economic and political Weekly, November, 9th, 2579.

39. Selig Harrison, India the Most Dangerous...opcit pp. 206-212 and Choudary, (1955). A Brief History of the Kammas, Sangam Tarlmudi, Guntur. 98-123

40. Bhargava. G. S, A study of the... opcit, 2, 14, pp.22-34.

41. Elliot, M. Carolyn, "Caste and Faction among the Dominant Castes, the Reddis and Kammas of Andhra" Caste in Indian Politics (ed) by Rajini Kothari, Quoted in V. Krishna Rao, Communism in Andhra Pradesh, Hyderabad, p. 133.

42. Ibid. p. 134 .

43. Seshadri K, “The Communist Party in Andhra Pradesh in state politics in India. Quoted in Ibid, p. 134.

44. Kulak, a Russian word, means Rich peasant and pettamdar, a Telugu word meaning head of caste or tribe.

45. Rao. CV.K. (1955). Rastra Communist Nayakatvapu Bandaram,(Bluff of the Andhra Communist Leadership), Masulipatnam, 1955, p. 28 
